\title{
A new species of Pagurus (Crustacea: Decapoda: Paguridae), new records and a redescription of hermit crabs from the Mexican Pacific
}

\author{
MANUEL AYÓN-PARENTE and MICHEL E. HENDRICKX \\ Laboratorio de Invertebrados Bentónicos, Unidad Académica Mazatlán, Instituto de Ciencias del Mar y Limnología, \\ Universidad Nacional Autónoma de México, P.O. Box 811, Mazatlán, Sinaloa, 82000, Mexico. \\ E-mail: michel@ola.icmyl.unam.mx.
}

\begin{abstract}
SUMMARY: New records are provided for three species of little-known pagurids. All the material reported was collected by the R/V "El Puma" in the central Gulf of California during the GUAYTEC II cruise. New material is reported for Iridopagurus haigae García-Gómez, 1983, Enallopagurus spinicarpus (Glassell, 1937), and Solenopagurus diomedeae (Faxon, 1893), and these two latter species are redescribed. A new species of hermit crab of the genus Pagurus Fabricius, 1775, is described and illustrated in detail. Among the eastern Pacific species of Pagurus, this new species resembles Pagurus meloi Lemaitre and Cruz Castaño, 2004, P. imarpe Haig, 1974 and P. delsolari Haig, 1974, but differs from these three species in the armature and setation of the chelipeds and second and third pereopods, the shape and armature of the telson, and the number of rows of scales on pereopodal rasp and the presence of a preungual process.
\end{abstract}

Keywords: hermit crabs, Paguridae, new species and records, Gulf of California.

RESUMEN: Una nueva especie de Pagurus (Crustacea: Decapoda: Paguridae), nuevos Registros y Redescripción DE CANGREJOS ERMITAÑOS PARA El PAĆ́fICO MEXICANO. - Se proporcionan nuevos registros de tres especies de paguridos poco conocidos, Iridopagurus haigae García-Gómez, 1983, Enallopagurus spinicarpus (Glassell, 1937) y Solenopagurus diomedeae (Faxon, 1893) recolectados durante el crucero GUAYTEC II abordo del B/O "El Puma” en el golfo de California central; además se proporciona una redescripción para las dos últimas especies. Se describe e ilustra en detalle una nueva especie de Pagurus Fabricius, 1775. La nueva especie de Pagurus presenta similaridad con Pagurus meloi Lemaitre and Cruz Castaño, 2004, P. imarpe Haig, 1974 y P. delsolari Haig, 1974, pero se diferencia de estas últimas por la armadura y la setación de los quelípedos y los pies ambulatorios, la forma y la armadura del telson, y el número de líneas de escamas sobre la raspa propodal y la presencia de un proceso preungual en los cuartos pereiópodos.

Palabras clave: cangrejos ermitaños, Paguridae, nueva especie y nuevos registros, golfo de California.

\section{INTRODUCTION}

The hermit crab fauna of the eastern tropical Pacific consists of one species of Coenobitidae, 37 species of Paguridae, 51 species of Diogenidae, and 6 species of Parapaguridae (Hendrickx and Harvey 1999, Lemaitre 1999, Lemaitre and Cruz-Castaño 2004, Ayón-Parente and Hendrickx 2010). Although many new species have been described in recent years for this region, new samples and reviews of unidentified material held in regional or local collections have provided more information on several taxa of this group of decapod crustaceans.

In the eastern tropical Pacific there are several poorly-known species of hermit crabs that have only been collected very rarely. This is particularly true for species found below $100 \mathrm{~m}$ depth and for which there is a significant lack of information related to their taxonomy, distribution, ecology and biology. Many records of Mexican deep-water hermit crabs 
were based on samplings made by the steamer "Albatross" in 1891, the Templeton Crocker's yacht "Zaca" in 1936, and the "Velero III" in 1936-40 (see Faxon 1895, Glassell 1937, McLaughlin 1982). Some species collected during these cruises have never been found again (Ayón-Parente 2009, Hendrickx and Ayón-Parente 2011).

In August 1987, the Instituto Tecnológico Superior de Monterrey (ITESM), Guaymas, Mexico, organized the GUAYTEC II cruise on board the R/V "El Puma", in the central Gulf of California. Most specimens of stomatopod and decapod crustaceans collected during this cruise were made available to one of the authors (MEH) through the courtesy of Lloyd T. Findley, chief scientist of the cruise (see Hendrickx 1990). In 2007, however, some additional specimens from that cruise were found when the remains of the ITESM marine invertebrate collection were transferred to the Regional Collection of Marine Invertebrates (EMU), at the Universidad Nacional Autónoma de México (UNAM), in Mazatlán. This material included specimens of the rare pagurids E. spinicarpus (Glassell, 1937), I. haigae García-Gómez, 1983, and S. diomedeae (Faxon, 1893), as well as a specimen of an undescribed species of Pagurus Fabricius, 1775, which was also collected during the TALUD XIV cruise in the northern Gulf of California. This material is reported herein.

\section{MATERIALS AND METHODS}

The material examined was collected with the R/V "El Puma" during the GUAYTEC II (organized by the ITESM in August 1987) and TALUD XIV (organized by the UNAM in April 2011) cruises in the northern and central Gulf of California. The specimens were captured using an $11.6 \mathrm{~m}$ commercial otter-trawl (5.7 $\mathrm{cm}$ stretched mesh) (GUAYTEC II) or a $2.35 \mathrm{~m}$ wide by $0.95 \mathrm{~m}$ high standard benthic sledge equipped with an outer collecting net of ca $5.5 \mathrm{~cm}$ (2 1/4") stretched mesh and an inner net of ca $2.0 \mathrm{~cm}$ (3/4") stretched mesh (TALUD XIV). The material examined is deposited in the Mazatlán collection (EMU), Mexico. We reviewed the type material of Enallopagurus spinicarpus (Glassell, 1938) (Crustacean Collection, Natural History Museum of Los Angeles County, LACM-CR) and Solenopagurus diomedeae (Faxon, 1893) (Invertebrates Collection, Harvard University, MCZ). We followed McLaughlin (1974) for general terminology, Lemaitre (1989) for type and division of gill lamellae, and McLaughlin (2003) for the use and significance of the term "semichelate". The measurement used is shield length (SL, in $\mathrm{mm}$ ), from the midpoint of the rostral lobe to the midpoint of the posterior margin of the shield. The length of the ocular peduncle was obtained by measuring the total length of the ultimate peduncular segment, including the cornea, on the lateral face of the peduncle. Other abbreviation: Sta., sampling station.

\section{TAXONOMY}

Family PAGURIDAe Fabricius, 1775

Enallopagurus spinicarpus (Glassell, 1938) (Figs. 1-4)

Pylopagurus spinicarpus Glassell, 1937: 256 (nomen nudum); 1938: 1. Walton, 1954: 151, pl. 43, Fig. C. Gordan, 1956: 340. Scanland and Hopkins, 1969: 230.

Enallopagurus spinicarpus. McLaughlin, 1981: 7; 1982: 844, Figs. 7a, 8a, d. Lemaitre and Alvarez-León, 1992: 46. Hendrickx, 1993: 283. Hendrickx and Harvey, 1999: 371. Lemaitre and McLaughlin, 2003: 471. Hendrickx, 2005: 173. Lemaitre et al., 2010: 16, Fig. 2a.

Material examined. Male holotype (SL $2.3 \mathrm{~mm}$ ) and 1 ovigerous female paratype (SL $2.2 \mathrm{~mm}$ ), Puerto Refugio $\left(29^{\circ} 32^{\prime} 46^{\prime}\right.$ 'N, $113^{\circ} 33^{\prime} 46^{\prime}$ 'W), Angel de la Guardia Island, Gulf of California, Mexico, 4 March 1936, 117 m, AHF-366 (ex-USNM-75432). 1 ovigerous female (SL $2.5 \mathrm{~mm}$ ), Central Gulf of California, Mexico, GUAYTEC II cruise, Sta. 69a (29²9’ N, 113'23’W), R/V “El Puma”, 11 August 1987, 83-88 m, otter trawl (EMU-9265).

Redescription. Shield (Figs. 1A, 4A) as long as broad or slightly longer than broad, transversally convex; dorsal surface with scattered tufts of long setae; margin between rostrum and lateral projections concave; rostrum obtusely triangular, unarmed or ending in small acute spine, exceeding in distal extension the lateral projections; lateral projections triangular, with small marginal spine.

Ocular peduncles moderately long, 0.7-0.8 length of shield; dorsal surfaces each with tufts of long setae; cornea dilated, corneal diameter 0.3 of peduncular length; ocular acicles triangular or ovate, with one strong submarginal spine, separated basally by 0.8 of the entire basal width of one acicle.

Antennular peduncles, when totally extended, overreaching distal margins of corneas by 0.5 to 0.8 of the length of the ultimate segment; ultimate segment with row of short setae on dorsal surface; penultimate segment with scattered tufts of short, fine setae; basal segment with one strong spine at laterosubdistal margin.

Antennal peduncles, when totally extended, exceeding by 0.5 ocular peduncles; fifth segment with tufts of long setae on dorsal and ventral margins; fourth segment with scattered tufts of long setae; third segment with tuft of long setae at ventrodistal margin; second segment with dorsolateral distal angle strongly produced, usually terminating in bifid spine, mesial margin armed with 2 or 3 small spines, dorsomesial distal angle with one spine; first segment with lateral margin unarmed, ventrolaterosubdistal margin with one small spine. Antennal acicle slender, curving outwardly, sharp, reaching base of cornea, with few tufts of long setae. Antennal flagella with short setae $\leq$ one article in length, and one or two long setae $>$ three articles in length.

Mandible without distinguishing characters. Maxillule (Fig. 2A) with one stiff bristle on moderately well developed internal endopod lobe; external lobe slightly 


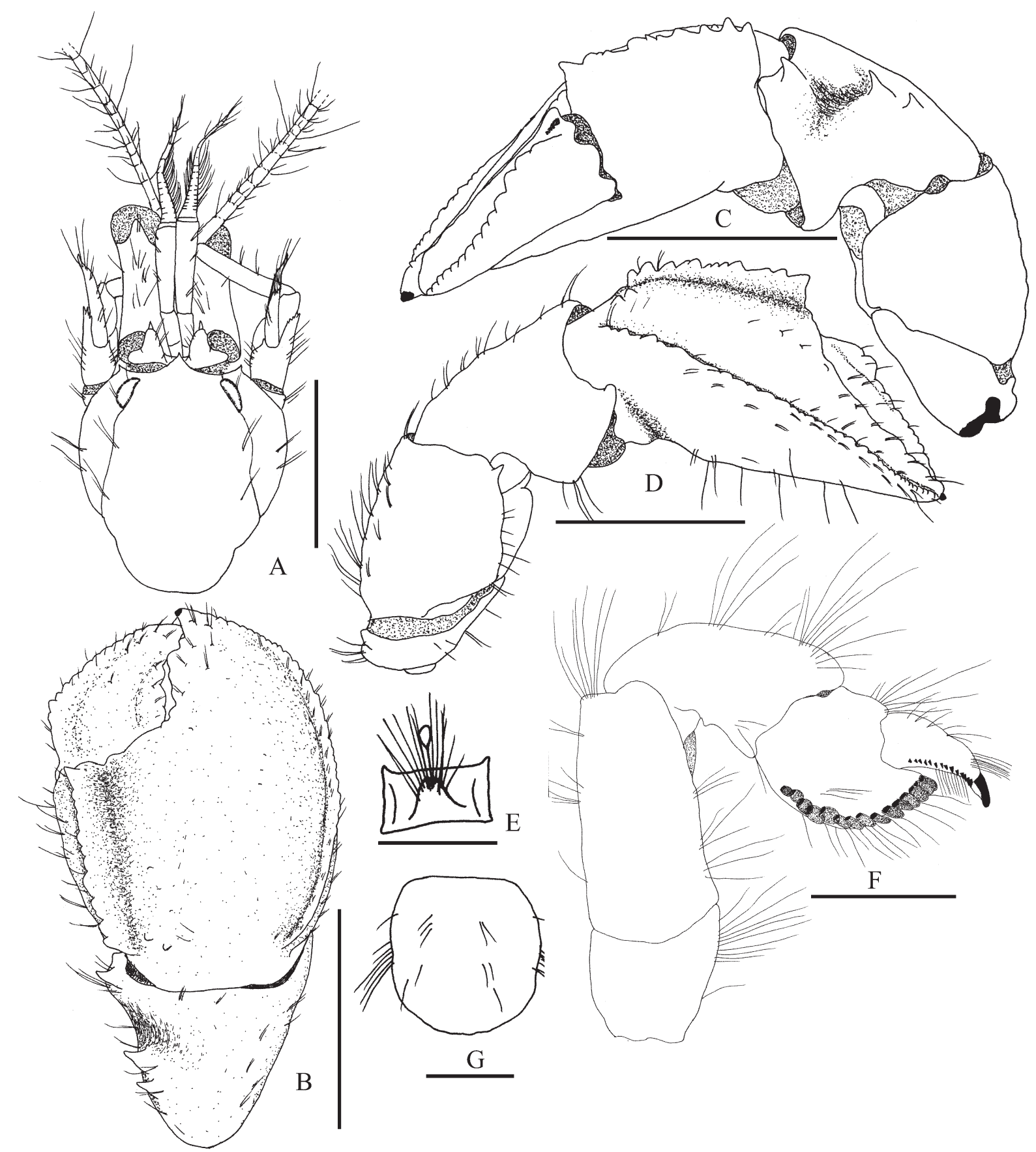

FIG. 1. - Enallopagurus spinicarpus (Glassell). Ovigerous female (SL $2.5 \mathrm{~mm}$ ), EMU-9265, Gulf of California. A, shield and cephalic appendages, dorsal view; B, right chela and carpus (dorsal view); C, right cheliped (mesial view, setae omitted); D, right cheliped; E, anterior lobe of sternite XII (third pereopods), ventral view; F, right fourth pereopod (lateral view); G, telson, dorsal view. Scale bars: A-D 2 mm, E-G 0.5 mm.

produced, proximal endite subrectangular to subquadrate. Maxilla (Fig. 2B) with endopod approximately equal to scaphognathite in distal extension. First maxilliped (Fig. 2C) with basal segment of exopod slender, endopod reaching 0.7 of exopod length. Second maxilliped (Fig. 2D) without distinguishing characters. Third maxilliped (Fig. 2E) with basis-ischium fusion apparently complete; basis with two or three strong spines; crista dentata well developed, accessory tooth present; merus with small spine on dorsodistal margin. Sternite of third maxillipeds with strong spine on either side of midline.

Chelipeds dissimilar and unequal, right much larger (Figs. 1B-D, 4B-C). Dactyl as long as palm, moderately broad; cutting edge with row of calcareous teeth, terminating in minute corneous claw; overlapped by fixed finger; dorsal surface slightly elevated in midline, with row of small spines or spinules; dorsomesial 


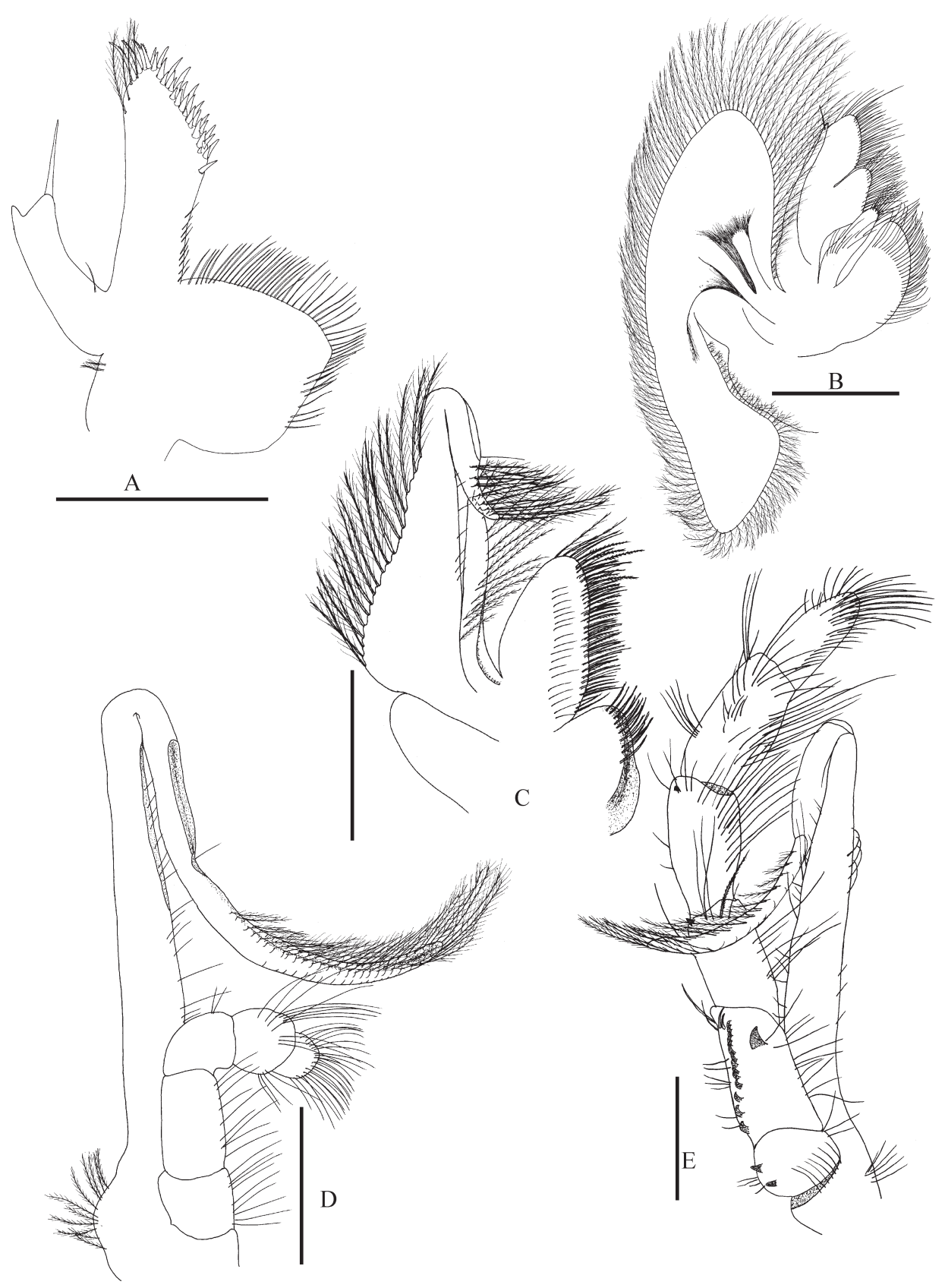

FIG. 2. - Enallopagurus spinicarpus (Glassell). Left mouthparts, inner view. Ovigerous female (SL 2.5 mm), EMU-9265, Gulf of California. A, maxillule; B, maxilla; C, first maxilliped; D, second maxilliped; E, third maxilliped. Scale bar: $0.5 \mathrm{~mm}$.

margin crested and with row of low teeth, the largest proximal. Palm larger than wide, equal in length to carpus, dorsal surface convex, unarmed, or occasionally slightly tuberculate; dorsomesial margin crested and armed with irregular row of small to moderately strong teeth; dorsolateral margin produced as minutely toothed ridge; cutting edge of fixed finger with a sharp, median tooth. Carpus armed with three spines on dorsomesial margin, two median and one distal, separated by concavity from prominent distal spine; dorsolateral margin rounded, with tufts of short setae. Merus triangular in cross section; dorsal margin with tufts of setae; ventrolateral margin with strong, distal spine. Ischium with row of small spines on ventromesial margin.

Left cheliped (Fig. 3A-C, 4D) reaching nearly to middle of palm of right cheliped. Dactyl 1.3 times the length of palm; cutting edge with row of corneous teeth, terminating in corneous claw; dorsal surface with row of small spines or spinules in midline; dorsomesial margin unarmed. Palm shorter than carpus; dorsal surface elevated in midline and armed with row of small spines; dorsomesial margin unarmed; dorsolateral margin with row of small teeth or spines. Carpus with row of moderate to strong spines on dorsolateral 


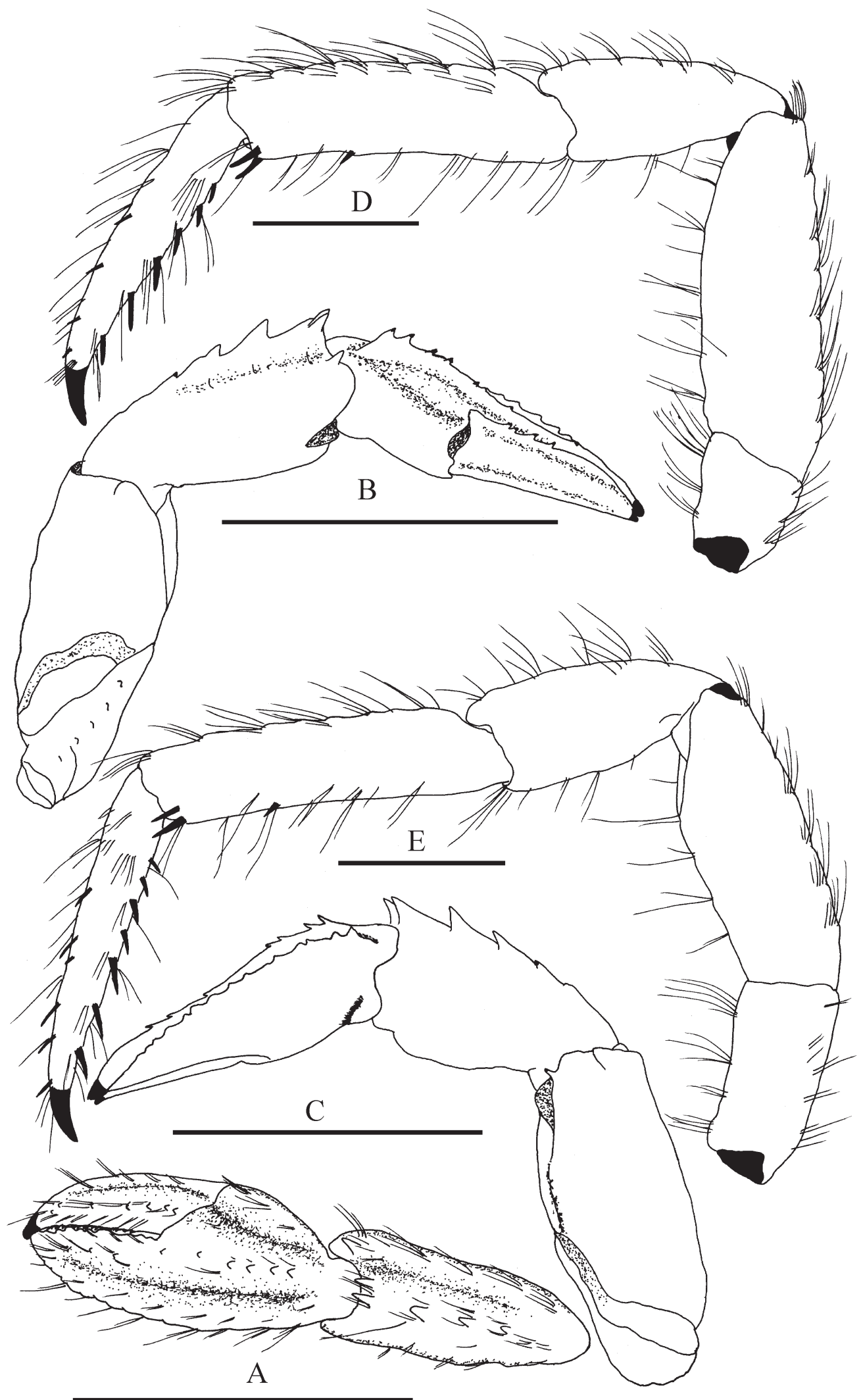

FIG. 3. - Enallopagurus spinicarpus (Glassell). Ovigerous female (SL $2.5 \mathrm{~mm}$ ), EMU-9265, Gulf of California. A, left chela and carpus (dorsal view); B, left cheliped (mesial view, setae omitted); C, left cheliped (lateral view, setae omitted); D, right second pereopod (mesial view); E, right third pereopod (mesial view). Scale bar: $2 \mathrm{~mm}$. 


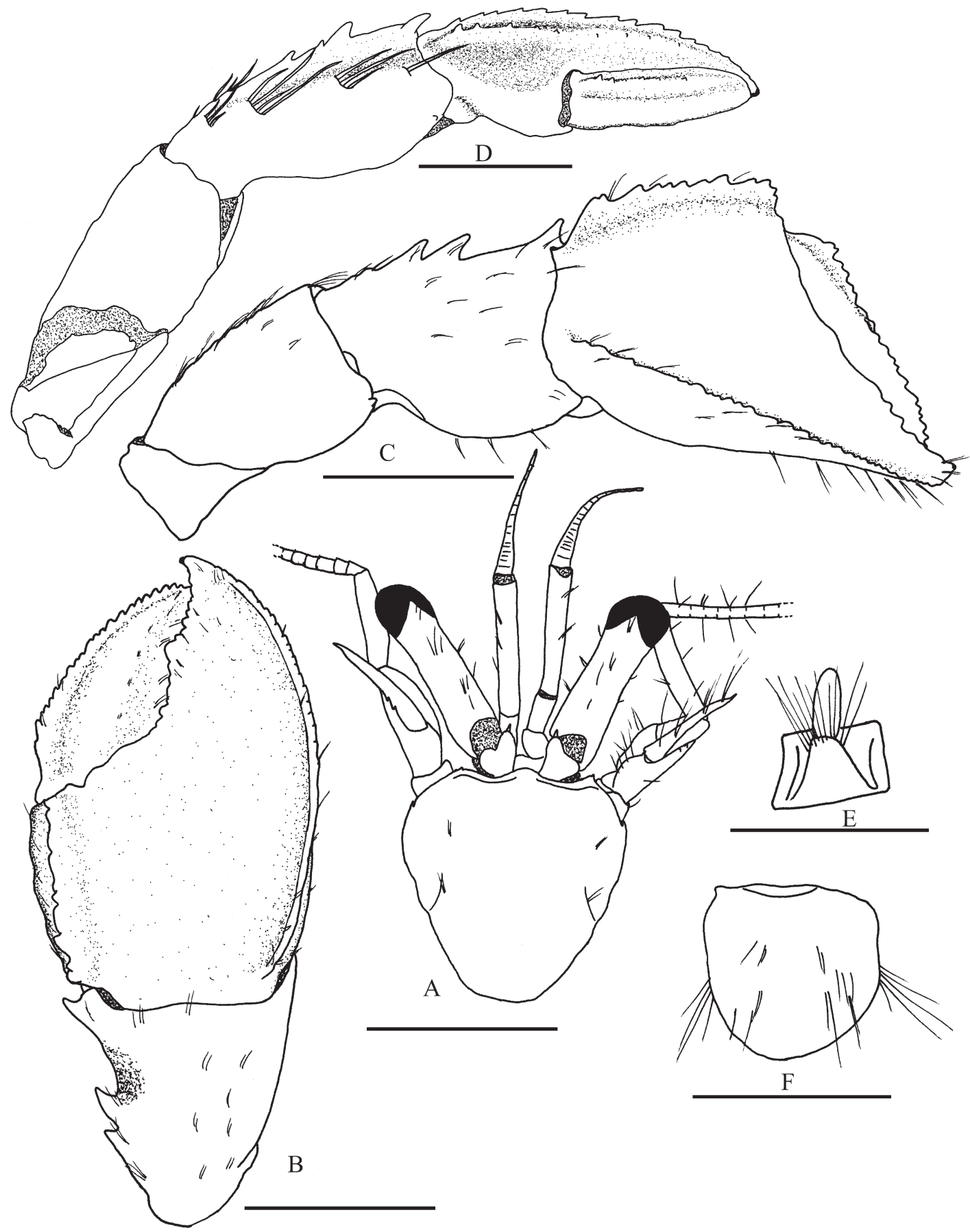

FIG. 4. - Enallopagurus spinicarpus (Glassell). Holotype male (SL $2.3 \mathrm{~mm}$ ), Puerto Refugio, Angel de la Guardia Island, Gulf of California, Mexico, AHF No. 366. A, shield and cephalic appendages (dorsal view); B, right chela and carpus (dorsal view); C, right cheliped (dorsolateral view); D, left cheliped (dorsomesial view); E, anterior lobe of sternite XII of third pereopods (ventral view); F, telson (dorsal view). Scale bars: A-D $2 \mathrm{~mm}, \mathrm{E}-\mathrm{F} 1 \mathrm{~mm}$.

margin, and one spine distally near dorsolateral margin; dorsomesial margin with one moderately strong spine distally and tufts of stiff setae on rest of margin. Merus with tufts of long setae on dorsal margin; ventrolateral margin with small spines or spinules and one strong spine distally. Ischium with row of small spines or granules on ventromesial margin.
Second and third pereopods (Fig. 3D, E) similar in armature, moderately broad. Dactyls 1.2-1.4 length of propodi; dorsal margin with tufts of long setae; mesial surface with strong, corneous spines near dorsal margin on the distal half; ventral margin with row of strong corneous spines and tufts of long setae. Propodi 1.1-1.3 times the length of carpi; dorsal surfaces with 
tufts of long setae; ventrodistal margin with two strong corneous spines, one additional spine on distal third. Carpi, meri and ischia each with tufts of long setae on dorsal and ventral margins.

Sternite XII (third pereopods) (Figs. 1E, 4E) subrectangular, bearing subtrapezoidal lobe, with tufts of long setae and often one capsulate seta.

Fourth pereopods (Fig. 1F) subchelate, each with long, slender preungual process at base of claw; dactyls long, 2.5 times longer than propodi measured along dorsal margin, with row of corneous spines on ventrolateral margin, posterior to claw; propodi each with single row of corneous scales in propodal rasp; carpi and meri unarmed, each with tufts of long setae on ventral and dorsal margins.

Telson (Figs. 1G, 4F) entire; terminal margin roundly convex and undivided, unarmed.

Habitat. The specimen was found in the gastropod Polinices uber (Valenciennes, 1832).

Distribution. From Eugenia Point to Tosca Point, west coast of Baja California; throughout the Gulf of California, Mexico; to Panama and Gorgona Island, Colombia; 16-175 m depth (McLaughlin 1982, Hendrickx and Harvey 1999).

Remarks. According to Walton (1954) and McLaughlin (1982), Enallopagurus spinicarpus is the most abundant species of the genus in the Mexican Pacific. It is closely allied to E. affinis (Faxon, 1893), but the latter has closely spaced, small, corneous-tipped spines or spinules on the dorsal surface of the right chela, while in E. spinicarpus these spines and spinules are lacking altogether. The examined female was bearing 102 eggs (egg mean size of $0.5 \mathrm{~mm}$ ).

Only small differences were observed when the GUAYTEC II cruise specimen was compared with the male holotype and the ovigerous female, and with the descriptions by Glassell (1938) and Walton (1954) for Pylopagurus spinicarpus. In both the type and paratype, the rostrum is blunt (Fig. 4A) and unarmed, whereas in our specimen the rostrum is obtusely triangular, ending in a small acute spine. Both Glassell (1938) and Walton (1954) included the following description: "carpus of minor cheliped with two rows of spines, one on the crest, the other below on the inner side". However, our revision of the type material observed by these two authors clearly showed that the carpus is armed with only one row of spines on the crest, and the inner side "row of spines" actually corresponds to thick bristles (Fig. 4D), as in the GUAYTEC II specimen. Glassell (1938) and Walton (1954) also mentioned that the second and third pereopods have an unarmed dorsal surface. According to Walton (1954), these two pereopods propodi have one spinule on the distal end of the medial surface, and the dactyls are spinulose beneath. Walton's statement probably refers to the presence of a single spinule on the ventral margin of the propodi; spinulose dactyls were observed on all three specimens examined. Neither Glassell (1938) nor Walton (1954) mentioned the presence of a row of spines on the mesial surface of dactyls, a character mentioned but not illustrated by McLaughlin (1982), but which is illustrated in the present study (Fig. 3D, E).

\section{Iridopagurus haigae García-Gómez, 1983}

Iridopagurus haigae García-Gómez, 1983: 14, 46, Figs. 5, 6 a-g. Glassell, 1937: 263 (in part). Hendrickx and Harvey, 1999: 371 (in part). Hendrickx, 2005: 173 (in part).

Material examined. One ovigerous female (SL $2.3 \mathrm{~mm}$ ), Central Gulf of California, Mexico, GUAYTEC II cruise, Sta. 69a (29²9'N, $\left.113^{\circ} 23^{\prime} \mathrm{W}\right), \mathrm{R} / \mathrm{V}$ “El Puma”, 11 August 1987, 83-88 m, otter trawl (EMU-9266).

Habitat. The specimen was collected in the gastropod Polystira nobilis (Hinds, 1843).

Distribution. West coast of Baja California; northern and central Gulf of California, Mexico; Galapagos Islands, Ecuador; 18-274 m (García-Gómez 1983).

Remarks. This is the first record since this species was initially described. According to García-Gómez (1983) female pleopods are unknown and are described here: four biramous unpaired pleopods; second pleopod with external ramus equal in length to internal ramus; third to fifth pleopods with external rami moderately developed, internal rami reduced. The ovigerous females reported by García-Gómez (1983) were collected in January and February and our material was collected in August. Female was bearing 114 eggs (egg mean size of $0.5 \mathrm{~mm}$ ).

Solenopagurus diomedeae (Faxon, 1893)

(Figs. 5-8)

Catapagurus diomedeae Faxon, 1893: 171; 1895: 57, pl. 13, Fig. 2 a-d. Glassell, 1937: 262. Hendrickx 1993: 309. Hendrickx and Harvey, 1999: 371. Hendrickx, 2005: 173.

Solenopagurus diomedeae de Saint Laurent, 1968: 926; 1970: 1454, Figs. 2, 13, 14, 16, 18. McLaughlin et al., 2010: 37.

Material examined. Male holotype (SL $2.8 \mathrm{~mm}$ ), Bay of Panama, Panama, 23 February 1891, Albatross Sta. 3355 (7¹2’20’’N, $\left.80^{\circ} 55^{\prime} 00^{\prime \prime} \mathrm{W}\right), 280 \mathrm{~m}$ (MCZ-4518). One male (SL $3.4 \mathrm{~mm}$ ), Central Gulf of California, Mexico, GUAYTEC II, Sta. 77 (28 $39^{\prime}$ N, $\left.112^{\circ} 12^{\prime} \mathrm{W}\right), \mathrm{R} / \mathrm{V}$ “El Puma”, 13 August 1987, 94-97 m, otter trawl (EMU-9267).

Redescription. Eleven pairs of intermediate branchiae. Shield (Fig. 5A, 8A) as long as broad or broader than long; dorsal surface with tufts of long setae near to lateral margins; anterolateral margins sloping; lateral margins slightly convex; anterolateral angle with a slit; anterior margin between rostrum and lateral projections concave; posterior margin subtruncate or rounded; rostrum short, obtusely triangular, unarmed or ending in a small acute spine, extending anteriorly as much as lateral projections; lateral projections bluntly triangular, each armed with small marginal spine. 

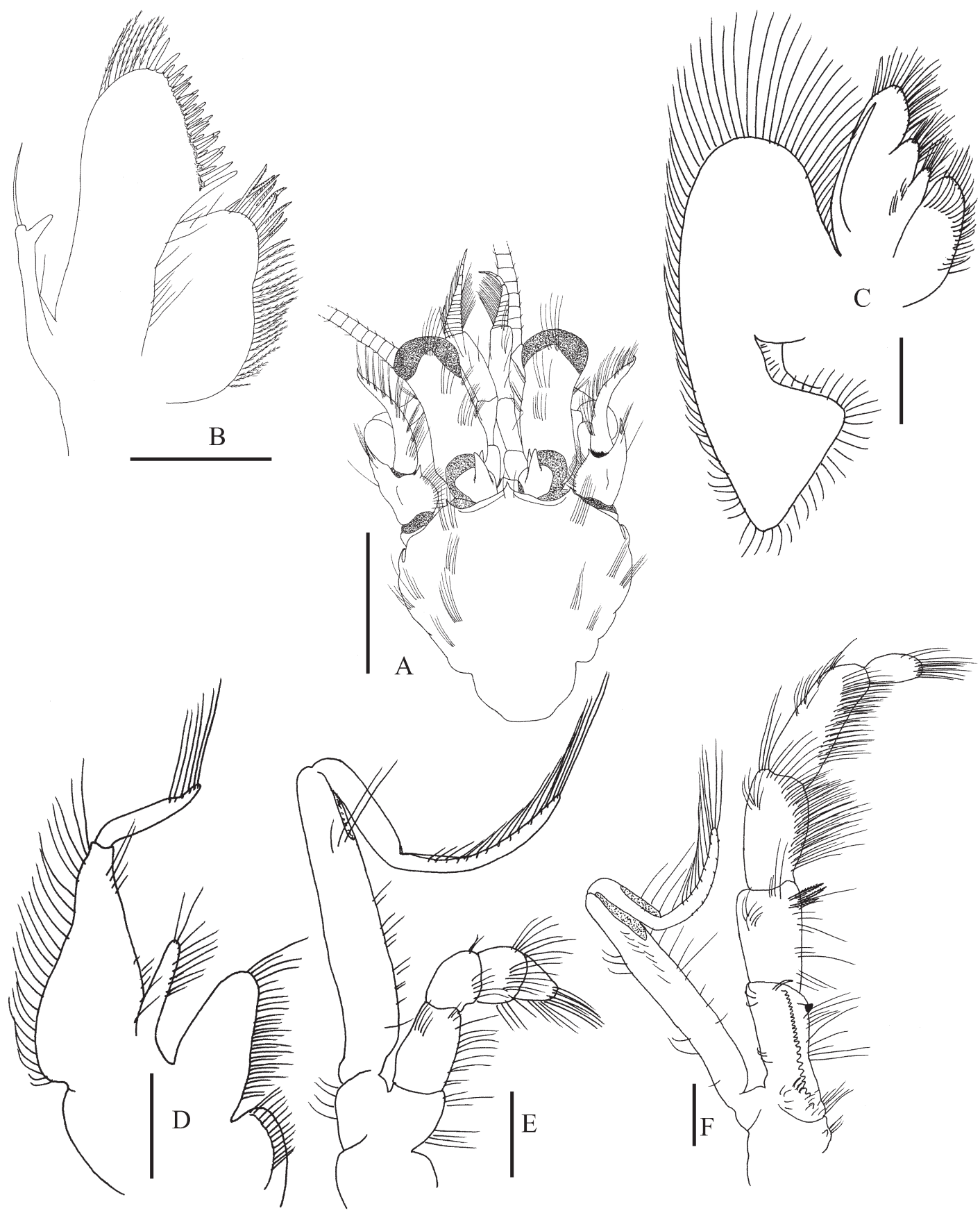

FIG. 5. - Solenopagurus diomedeae (Faxon). Male (SL 3.4 mm), EMU-9267, Gulf of California. A, shield and cephalic appendages (dorsal view); B-F, left mouthparts (inner view); B, maxillule; C, maxilla; D, first maxilliped; E, second maxilliped; F, third maxilliped. Scale bars: A $2 \mathrm{~mm}$, B-F $0.5 \mathrm{~mm}$.

Ocular peduncles moderately long, 0.6-0.8 length of shield, cylindrical, curving outwardly, dorsal surface with tufts of long setae; cornea slightly dilated, corneal diameter 0.4 length of peduncle. Ocular acicles triangular, ending in strong spine, concave on dorsal surface, and with strong submarginal spine; separated basally by basal width of 1 acicle.

Antennular peduncles long, when totally extended exceeding by 0.5 the length of ocular peduncles; ultimate segment with few tufts of long setae on dorsal surface; penultimate segment naked; basal segment with small spine at laterosubdistal margin.

Antennal peduncles long, slightly exceeding ocular peduncles. Fifth segment with tufts of setae on dorsal and ventral margins; fourth segment unarmed; third segment with ventrodistal margin weakly produced, with 1 small spine; second segment with laterodistal angle strongly produced, terminating in single, sharp spine, dorsomesial distal angle with 1 spine; first segment unarmed. Acicle long, slender, curving out- 

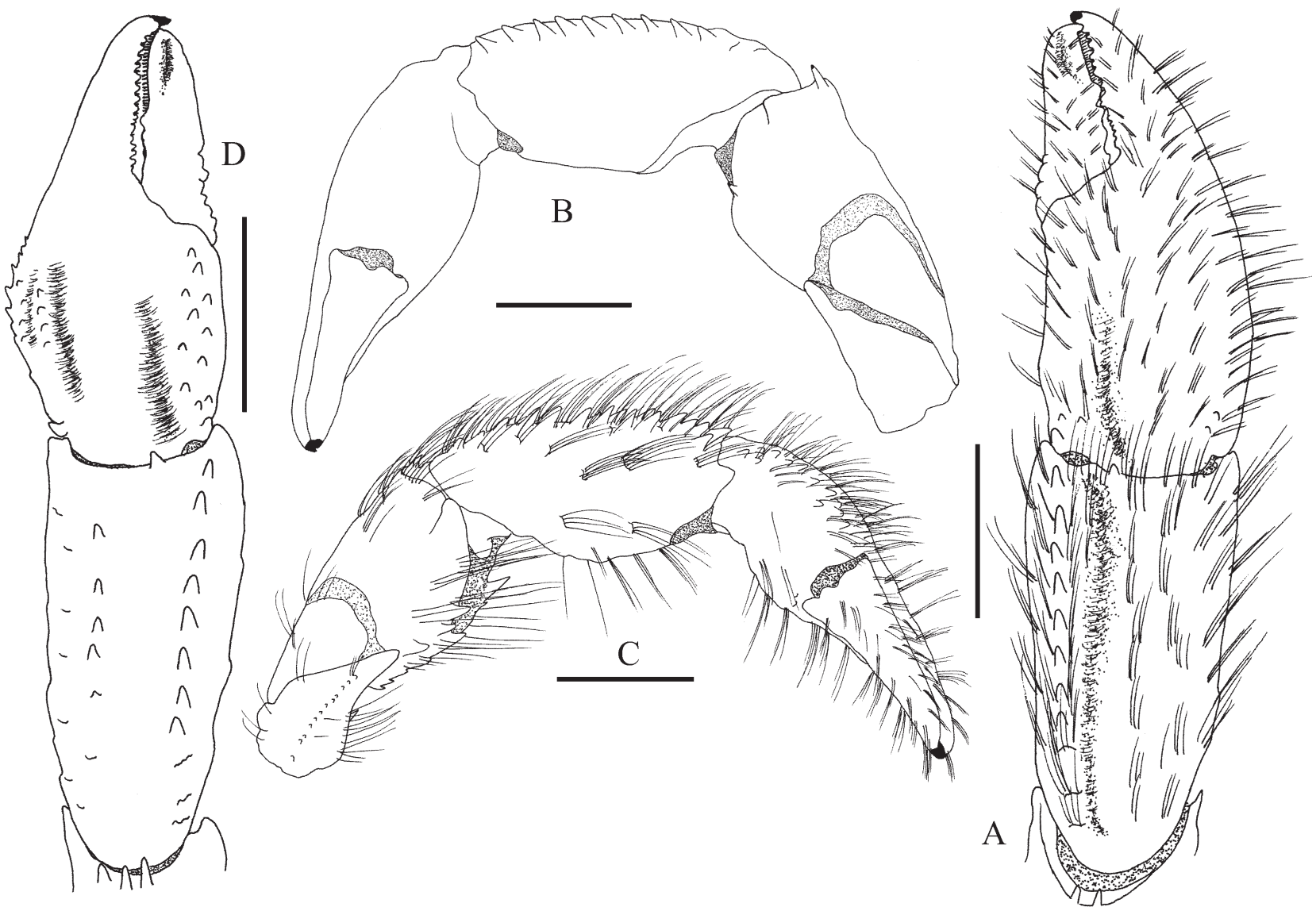

Fig. 6. - Solenopagurus diomedeae (Faxon). Male (SL $3.4 \mathrm{~mm}$ ), EMU-9267, Gulf of California. A, right chela and carpus (dorsal view); $\mathrm{B}$, right cheliped (mesial view, setae omitted); C, left cheliped (mesial view); D, left chela and carpus (dorsal view, setae omitted). Scale bar: $2 \mathrm{~mm}$.

wardly, reaching to 0.8 length of ultimate antennal segment, unarmed, with sharp tip. Antennal flagella long, exceeding the length of chelipeds, with short setae on each article.

Maxillule (Fig. 5B) with 1 stiff bristle on distal margin of endopod, external lobe well developed, not recurved, proximal endite subtriangular. Maxilla (Fig. 5C) with endopod distally exceeding scaphognathite. First maxilliped (Fig. 5D) with basal segment of exopod slender, endopod reaching 0.5 length of exopod. Second maxilliped (Fig. 5E) without distinguishing characters. Third maxilliped (Fig. 5F) with basisischium fusion incomplete; coxae and basis each with 2 spines; crista dentata well developed, accessory tooth present; meri, carpi, propodi and dactyls unarmed.

Chelipeds unequal, right (Figs. 6A, B, 8B) slightly larger than left; dactyl 0.7-1.0 length of palm; cutting edge with calcareous teeth on proximal half, corneous teeth on distal half; a small, terminal, corneous claw; dorsal and mesial surfaces with rows of tufts of long setae. Palm 0.7-0.8 length of carpus; mesial margin almost straight; dorsal surface slightly convex, 1-3 small proximal spines near dorsomesial margin; lateral margin convex; all faces and fixed finger with tufts of long setae; fixed finger with cutting edge armed with calcareous teeth proximally, and calcareous teeth interspersed by small corneous spines distally, with small, terminal, corneous claw. Carpus relatively long, slightly longer than merus; dorsomesial margin with a row of strong or moderately strong spines with tufts of long setae at bases; dorsal surface with rows of tufts of long setae, distal margin with 1 small spine; dorsolateral margin rounded with an irregular row of tufts of long setae. Merus triangular in cross section; dorsal surface with tufts of long setae, distal margin with 2 strong spines; ventromesial margin with small spine distally and tufts of long setae; ventrolateral margin with a row of spines and tufts of long setae. Ischium with a row of small spines or spinules on ventromesial margin.

Left cheliped (Fig. 6C, D, 8C) with dactyl as long or slightly longer than palm, with dorsomesial margin and dorsal surface with tufts of long setae, mesial surface with some small spines proximally; cutting edge with calcareous teeth proximally and corneous teeth distally, terminating in small corneous claw. Palm 0.5 length of carpus; mesial margin almost straight; dorsomesial margin with 2 irregular rows of spines with tufts of long setae at bases; dorsal surface slightly convex, with rows of long setae and scattered small spines proximally; lateral margin convex, with a few small spines or gran- 


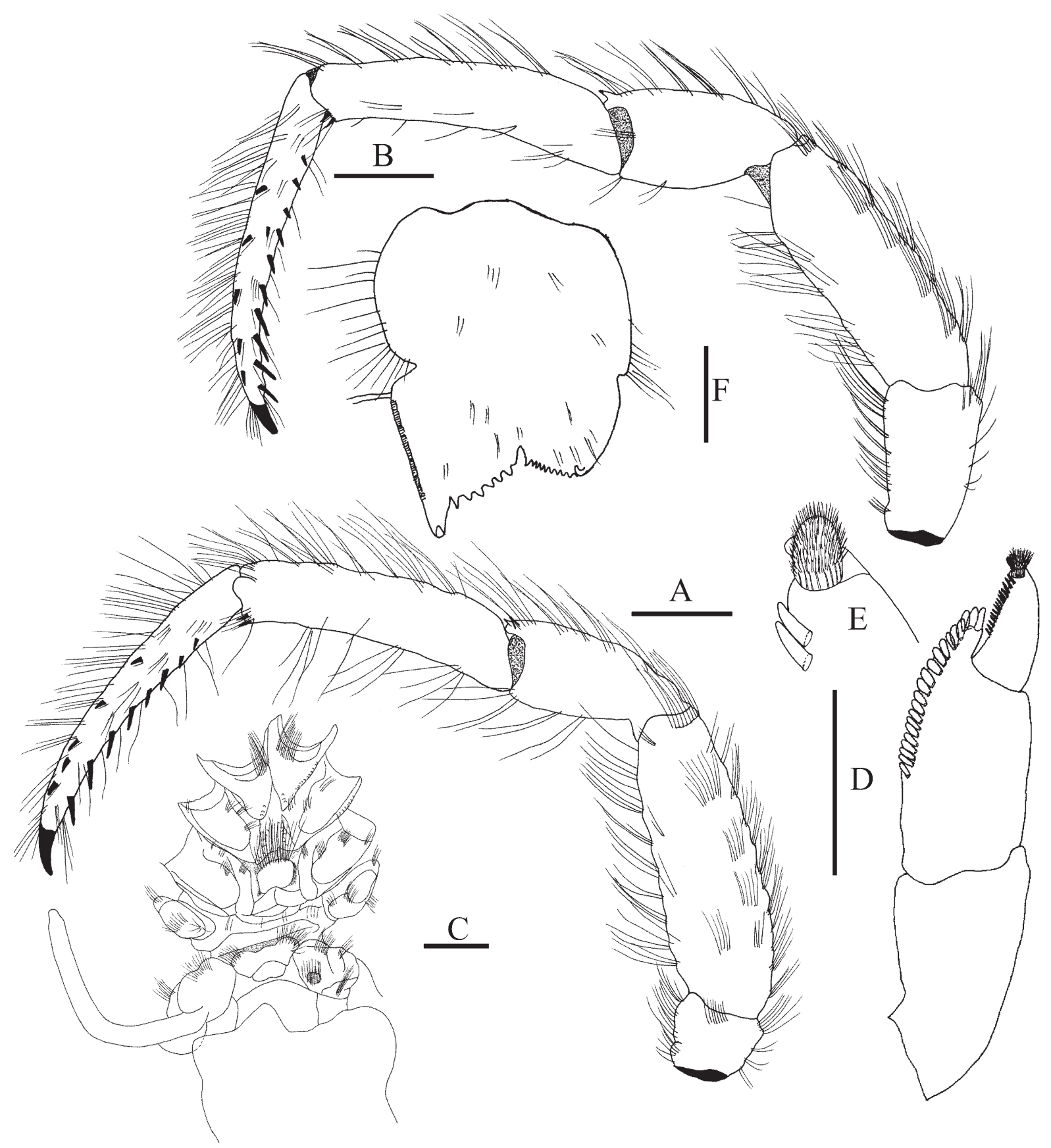

FIG. 7. - Solenopagurus diomedeae (Faxon). Male (SL 3.4 mm), EMU-9267, Gulf of California. A, right second pereopod (mesial view); B, right third pereopod (mesial view); C, thoracic sternites, coxae of pereopods and sexual tube (ventral view); D, dactyl, propodus and carpus of fourth left pereopod (lateral view, setae omitted); E, magnification of the tip of dactyl and preungual process of left fourth pereopod; F, telson (dorsal view). Scale bars: A-D $1 \mathrm{~mm}, \mathrm{E} 0.5 \mathrm{~mm}$.

ules and tufts of long setae; dorsolateral margin with a row of small spines on proximal half; fixed finger with tufts of long setae on dorsal and lateral surfaces, cutting edge with calcareous teeth proximally and calcareous teeth interspersed with small corneous spines distally; terminating in small corneous claw. Carpus as long as merus; dorsomesial margin with row of strong spines accompanied with tufts of long setae; dorsal surface with tufts of long setae, distal margin with 1-3 strong spines; dorsolateral margin with a row of spines increasing in size distally and tufts of long setae. Merus triangular in cross section; dorsal surface with tufts of long setae, distal margin with 2-3 strong spines; ventromesial and ventrolateral margins with strong spines and tufts of long setae. Ischium with row of small spines or spinules on ventromesial margin; ventrolaterodistal margin with 1 strong spine. Second and third pereopods (Figs. 7A, B, $8 \mathrm{D}$, E) similar in armature; dactyls 1.2-1.3 longer than 


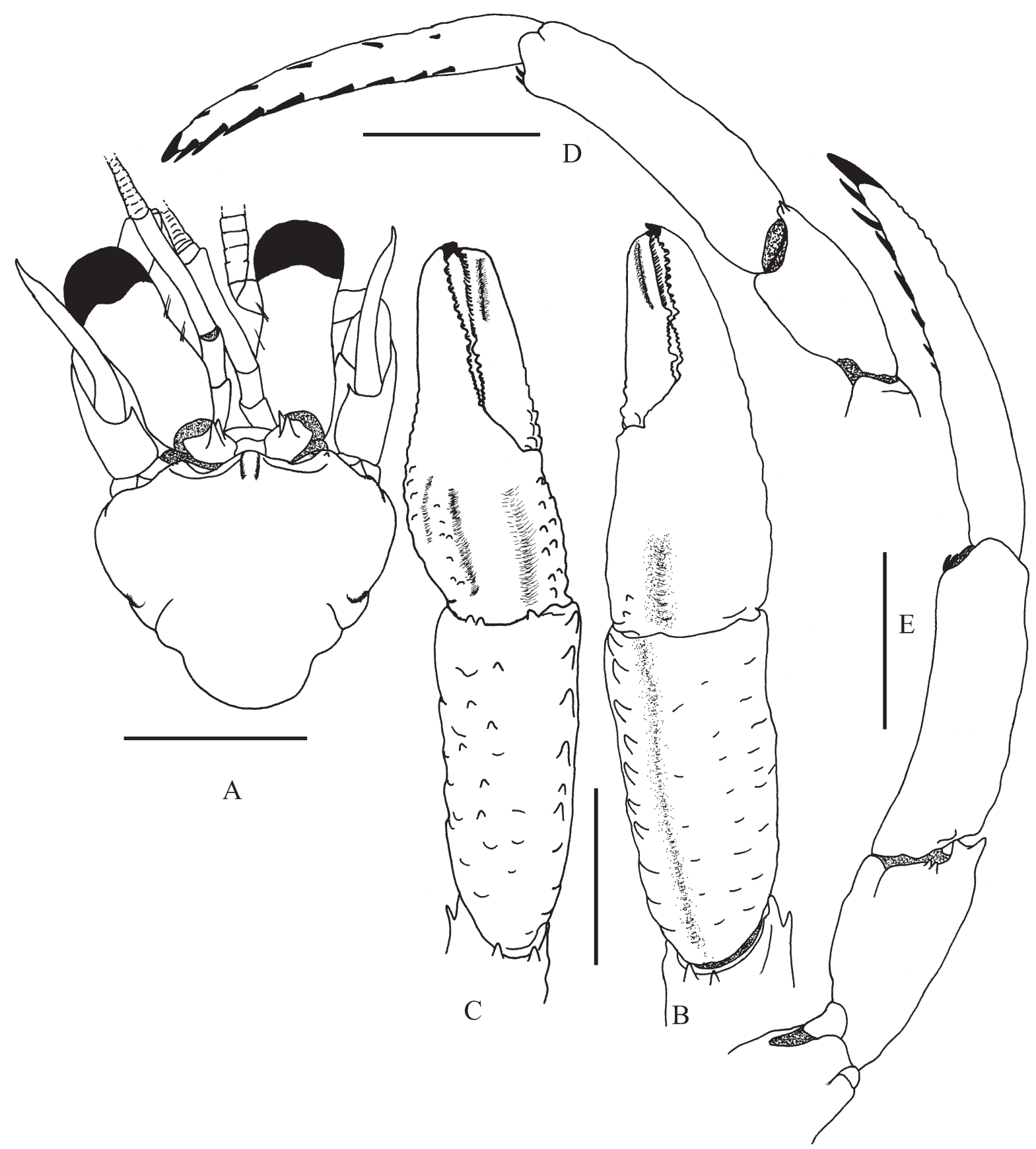

FIG. 8. - Solenopagurus diomedeae (Faxon). Holotype male (SL $2.8 \mathrm{~mm}$ ), MCZ-4518, Bay of Panama. A, shield and cephalic appendages (dorsal view, setae omitted); B, right chela and carpus (dorsal view, setae omitted); C, left chela and carpus (dorsal view, setae omitted); D, dactyl, propodus and carpus of right second pereopod (mesial view, setae omitted); E, dactyl, propodus and carpus of left second pereopod (lateral view, setae omitted). Scale bar: $2 \mathrm{~mm}$.

propodi; dorsal margins each with a row of long setae; mesial surfaces each with a row of large corneous spines near the dorsomesial margin; ventral margins each with a row of large corneous spines, terminating in large corneous claw. Propodi 1.4-1.5 longer than carpi; dorsal margins each with tufts of long setae; ventral margins each with 2 corneous, distal spines, and tufts of setae, the latter longer on second pereopods. Carpi 0.6-0.9 length of meri; dorsal surfaces each with 1 small distal spine and tufts of long setae; lateral and ventral surfaces with tufts of long setae. Meri each with tufts of long setae on dorsal and ventral margins. Ischia each with tufts of long setae on ventral and dorsal margins.

Sternite XII (third pereopods) (Fig. 7C) lobe with anterior margin subcircular and fringed with tufts of long setae.

Fourth pereopods (Fig. 7D, E) subchelate. Dactyls as long as propodi, each with well developed, sac- 
shaped preungual process, which is naked on its basal portion and distally is covered densely with relatively long seta-like filaments; ventrolateral margin with a row of corneous spines. Propodi each with a single row of lanceolated scales on distal 0.7. Carpi and meri unarmed.

Males with long sexual tube ( $>5$ coxal length) on right coxa of fifth pereopod (Fig. 7C), directed outward and curving over anterodorsal part of abdomen. Males with 3 biramous, unpaired left pleopods. Females with 4 biramous, unpaired left pleopods.

Telson (Fig. 7F) with lateral indentations separating anterior and posterior portions; posterior lobes separated by weak median cleft, each armed with small spines on posterior margin; posterolateral angles each with large, ventrally curved spine, lateral margin of left posterior lobe chitinous.

Habitat. The specimen was collected on sandy substrate in the gastropod Vokesimurex lividus (Carpenter, 1857); 94-97 m.

Distribution. Tiburon Island, Sonora, and Santa Inés Bay, Baja California, to Arena Bank, Baja California Sur, Gulf of California, Mexico, to Bay of Panama; Cocos and Galápagos Islands (Glassell 1937, de Saint Laurent 1970, Hendrickx and Harvey 1999).

Remarks. Until now only two species are known in the genus Solenopagurus de Saint Laurent, 1968, one on each side of the American continent. The western Atlantic species S. lineatus Wass, 1963, occurs from North Carolina to Surinam, and S. diomedeae is found in the eastern Pacific. Previous to this record, only eight specimens of this species had been reported: five male, two female and one ovigerous female.

Some small differences were found when the GUAYTEC II specimen was compared with the male holotype (Fig. 8A-E). In the male holotype the shield is broader than it is long and the rostrum is blunt and unarmed (Fig. 8A), while in our specimen the shield is as long as broad and the rostrum is short, obtusely triangular, ending in a small acute spine. Compared to the GUAYTEC II specimen, the proportion between ocular peduncles and the shield length is greater in the holotype. Chelipeds in the holotype are proportionally slender and the armature differs slightly with the GUAYTEC II material; in the holotype the carpi are armed with seven spines on the dorsomesial margin, whereas our specimen has eight spines. In his description of the second and third pereopods Faxon (1895: 58) stated that "the carpus is armed with a sharp tooth at the distal end of its upper side; propodus is twice as long as the carpus, the dactyl is considerably longer than the propodus, and like that segment is distinctly curved; it is tipped by a small horny nail". In the diagnosis of the genus, de Saint Laurent (1970: 1452, Figs. 10, 11) stated that the "second and third pereopods are unarmed with the exception of carpus that bears a distal spinule on dorsal margin. Dactyls are arcuate, longer than propodi, armed on ventral margin with long spine-like setae [corneous spines]". In both the type material and the GUAYTEC II specimen, the dactyls of the second and third pereopods are armed with a row of corneous spines on the ventral margin, and another near the dorsomesial margin, but this second row was not described either by Faxon (1895) or by de Saint Laurent (1970). The carpus of the left third pereopod (Fig. 8E) in the holotype bears 2 small spines on the laterodistal margin, a feature not observed in the GUAYTEC II due to the regenerating process of this appendage. Finally, in the GUAYTEC II specimen, the carpus of the second pereopods is armed with two spines, whereas in the holotype there is only one.

Pagurus findleyi n. sp. (Figs. 9-11)

Type material. Holotype, Central Gulf of California, Mexico,

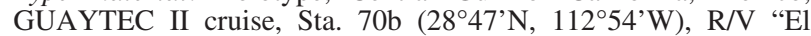
Puma”, 10 August 1987, female (SL 3.0 mm), 360-380 m, dredge (EMU-9268). Paratype, Gulf of California, Mexico, TALUD XIV

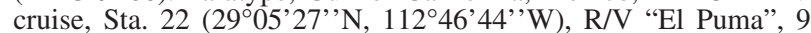
April 2011, 1 female (SL 3.7 mm), 380-390 m, dredge (EMU-9511).

Etymology. The species is named after Lloyd T. Findley, renowned icthyologist and chief-scientist of the GUAYTEC cruises, in recognition of his long and dedicated work in the Gulf of California. It is the genitive form derived from his surname "Findley".

Description. Eleven pairs of biserial gills weakly divided distally (Fig. 9A). Shield (Fig. 9B) slightly longer than broad; anterolateral margins sloping; anterior margin between rostrum and lateral projections concave; anterolateral angle with a slit; posterior margin roundly truncate; dorsal surface slightly inflated, convex, with a few tufts of setae. Rostrum triangular, long, subacute, clearly exceeding lateral projections, with a few setae. Lateral projections obtusely triangular, unarmed.

Ocular peduncles moderately stout, short, approximately 0.5 length of shield; slightly constricted medially, dorsal surface with row of tufts of long setae. Corneas a little dilated, width of each about 0.4 length of ocular peduncles. Ocular acicles bluntly subtriangular, narrow, weakly concave dorsally, tip subacute, with strong, submarginal spine; separated basally by about 0.5 basal width of 1 acicle.

Antennular peduncles, when totally extended, exceeding ocular peduncles by full length of ultimate segment. Ultimate segment with few long setae on dorsal surface subdistally and short setae proximally; penultimate segment with few short setae. Basal segment with strong spines on laterosubdistal margin.

Antennal peduncles moderately long, exceeding ocular peduncles by 0.5 length of ultimate segment; with supernumerary segment. Fifth segment unarmed, with scattered setae on dorsal and ventral margins. Fourth 


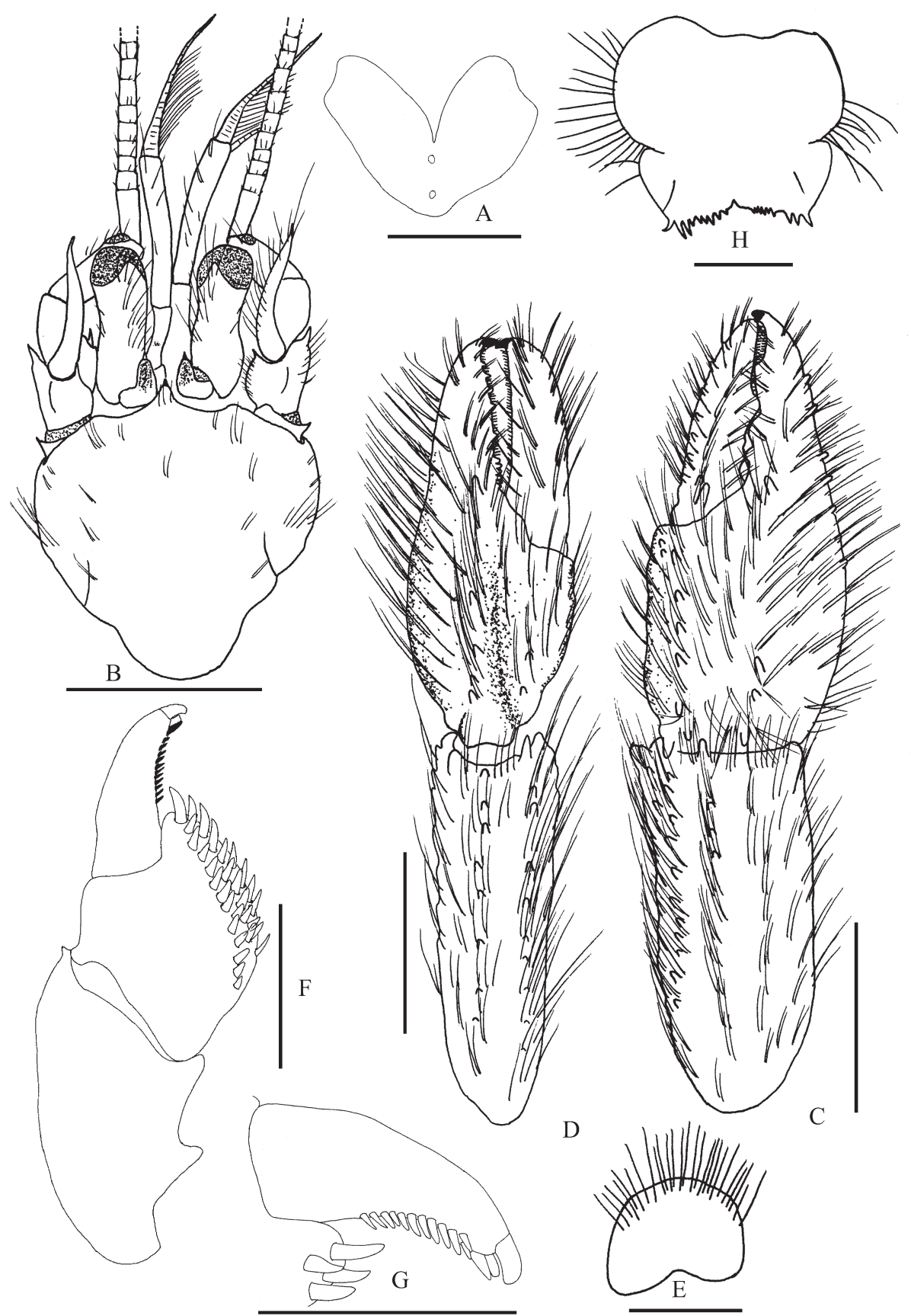

FIG. 9. - Pagurus findleyi n. sp. Female (3.0 mm), EMU-6268, Gulf of California. A, gill lamellae; B, shield and cephalic appendages (dorsal view); C, right chela and carpus (dorsal view); D, left chela and carpus (dorsal view); E, anterior lobe of sternite XII of third pereopods (ventral view); F, dactyl, propodus and carpus of right fourth pereopod (lateral view, setae omitted); G, dactyl of same pereopod (lateral view, setae omitted); H, telson, (dorsal view). Scale bars: A-C $2 \mathrm{~mm}, \mathrm{D}-\mathrm{H} 0.5 \mathrm{~mm}$.

segment unarmed, with scattered setae. Third segment with strong spine at ventrodistal margin, partially obscured by tufts of setae. Second segment with dorsolateral distal angle produced, terminating in strong spine, lateral margin unarmed; dorsomesial distal angle with strong spine, mesial margin with short setae. First segment with small spine on laterodistal margin. Antennal acicles moderately long, slightly exceeding length of ocular peduncles, reaching middle of ultimate antennal peduncle segment, terminating in strong, acute spine; dorsal surface and mesial margin with tufts of stiff setae. Antennal flagella long, exceeding tip of right cheliped, with a few short bristles equivalent to one or less than one flagellar article in length.

Mandibles (Fig. 10A) with cutting edge bearing two calcareous teeth. Maxillule (Fig. 10B) with external lobe of endopod moderately developed, recurved; internal lobe with long terminal bristle. Maxilla (Fig. 


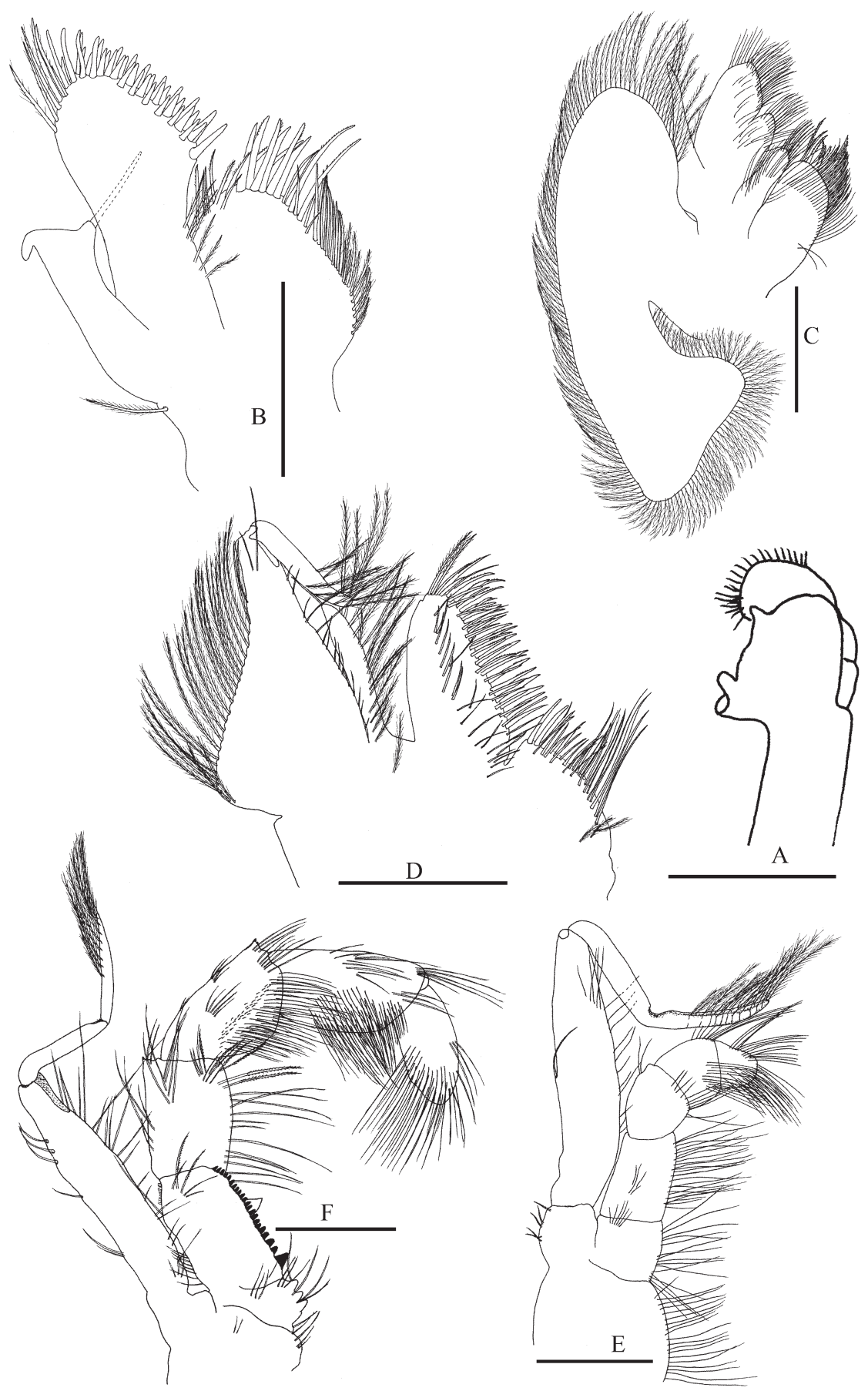

FIG. 10. - Pagurus findleyi n. sp. Female (3.0 mm), EMU-6268, Gulf of California. Left mouthparts, inner view. A, mandible; B, maxillule ; C, maxilla; D, first maxilliped; E, second maxilliped; F, third maxilliped. Scale bar: $0.5 \mathrm{~mm}$.

10C) with endopodite inflated basally, slightly exceeding scaphognathite in distal extension. First maxilliped (Fig. 10D) with endopodite approximately 0.7 length of exopodite; basal segment of exopodite inflated. Second maxilliped (Fig. 10E) without distinguishing characters. Third maxilliped (Fig. 10F) with basis bearing 3 to 4 strong spines; ischium with crista dentata well developed, consisting of 21 corneous-tipped teeth and one accessory tooth; merus and carpus each with spine at dorsodistal margin.

Chelipeds unequal, elongate. Right (Figs. 9C, 11A) with dorsal surface of merus, carpus and chela covered with tufts of long setae. Dactyl almost as long as palm, terminating in small, corneous claw, partly overlapped by fixed finger; cutting edge with calcareous teeth on proximal half, replaced distally by row of 


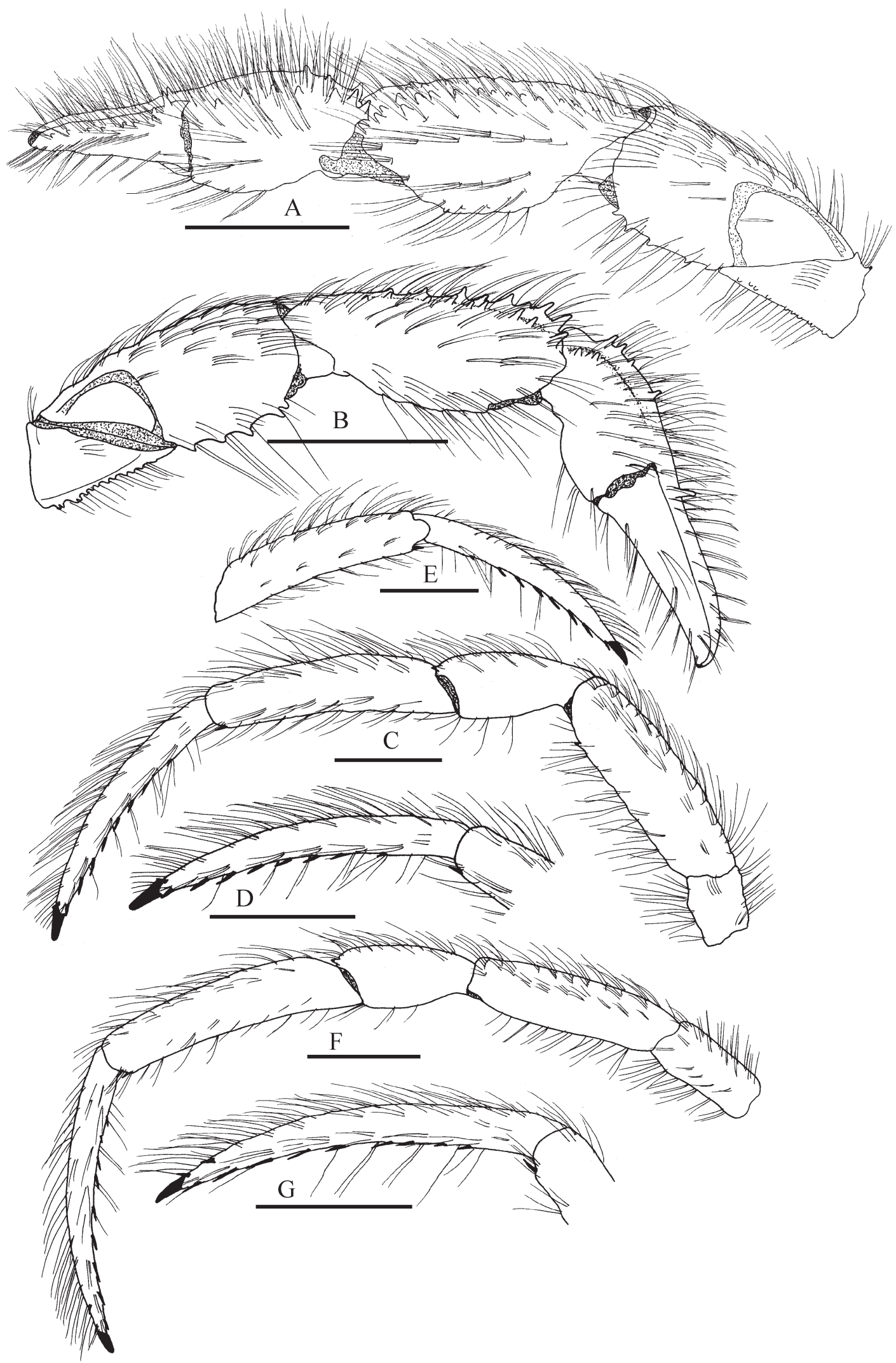

FIG. 11. - Pagurus findleyi n. sp. Female (3.0 mm), EMU-6268, Gulf of California. A, right cheliped (mesial view); B, left cheliped (mesial view); C, right second pereopod (mesial view); D, dactyl of same (mesial view); E, dactyl and propodus of same (lateral view); F, right third pereopod (mesial view); G, dactyl of same (mesial view). Scale bar: $2 \mathrm{~mm}$. 
small, corneous teeth; dorsomesial margin with row of moderately strong blunt or tubular spines; dorsal surface slightly flattened, with 2 proximal tubular spines; mesial and ventral surfaces unarmed. Palm elongate, 0.6 length of carpus; dorsal surface convex, with a row of three proximal tubular spines; dorsomesial margin with a row of short spines; dorsolateral margin with row of small tubular spines on distal 0.7 ; lateral surface unarmed; ventral surface with scattered small tubercles with setae. Fixed finger with 1 strong, proximal tubular spine near cutting edge; cutting edge with calcareous teeth proximally and small, corneous teeth distally. Carpus elongate, almost twice the length of palm; dorsomesial margin with row of blunt or tubular spines, increasing in size distally; dorsal surface with a row of small spines near dorsomesial margin, the rest of the surface with flattened granules; mesial face with scattered protuberances, ventromesial margin with an irregular row of protuberances, gradually becoming spines distally; dorsolateral margin not delimited, unarmed, lateral face unarmed; ventrolateral margin with short row of small to moderately strong spines distally, ventral surface unarmed. Merus subtriangular; dorsal surface with irregular rows of low protuberances accompanied by tufts of long setae; mesial and lateral faces unarmed, ventromesial and ventrolateral margins each with a single row of spines, strongest mesially. Ischium with a row of small spines on ventromesial margin, ventrolateral and ventrodistal margins with tufts of long setae. Coxa unarmed.

Left cheliped (Figs. 9D, 11B) moderately long, reaching to base of right dactyl, slender; surfaces with tufts of long, stiff setae. Dactyl as long as palm; cutting edge with row of small, corneous teeth; terminating in broad, corneous claw; dorsal surface unarmed. Palm moderately short, 0.6 length of carpus; dorsal surface convex, with irregular, single row of tubular spines, four proximal and one on the base of fixed finger; dorsomesial margin not delimited, with two small, tubular spines proximally; dorsolateral margin not delimited, with a few low granules proximally; lateral, mesial and ventral surfaces unarmed. Carpus elongate, subrectangular, exceeding length of merus; dorsomesial and dorsolateral margins each with a row of moderately strong spines; mesial and lateral faces with a few scattered, low protuberances or granules; ventromesial and ventrolateral margins with tufts of long setae. Merus subtriangular; dorsal surface with short, transversal rows of long setae; mesial and lateral faces with a few low protuberances; ventromesial and ventrolateral margins each with a single row of moderately strong spines. Ischium with a row of small spines or denticles on ventromesial margin. Coxa unarmed.

Second and third pereopods long (Fig. 11C-G.), reaching tip of right cheliped; dorsal and ventral surfaces with tufts of moderately long, stiff setae. Dactyls moderately elongate, somewhat exceeding length of propodi, ending in sharp corneous claw; dorsal margins each with a row of widely spaced, low protuberances; mesial faces with one small (second) or two (third) corneous spines dorsodistally; lateral faces unarmed; ventral margins each with a row of strong corneous spines, increasing in size distally. Propodi elongate, 1.3-1.5 length of carpi; dorsal surfaces each with row of low protuberances; mesial and lateral faces unarmed; ventral margins each with one corneous spine distally. Carpi each with small dorsodistal spine. Meri with dorsal surfaces each with a row of low protuberances; mesial face (second) with small spine on ventral margin distally. Ischia and coxae unarmed.

Sternite XII (third pereopods) with subsemicircular anterior lobe (Fig. 9E), anterior margin with long, stiff setae.

Fourth pereopods (Fig. 9F, G ) semichelate. Dactyls with small preungual process at base of claw and ventrolateral row of closely set, small, corneous spines. Propodal rasp with 3-4 rows of lanceolate scales, scales in posterior row smaller.

Fifth pereopods chelate. Dactyls with three rows of small ovate scales. Propodal rasp extending posteriorly to nearly midpoint of segment. Coxae almost symmetrical.

Female with paired gonopores and unpaired pleopods 2-5; pleopods 2-4 with both rami moderately developed; pleopod 5 weakly developed, uniramous.

Uropods asymmetrical. Telson (Fig. 9H) with posterior lobes symmetrical, separated by very shallow median cleft; terminal margins slightly convex, each with a row of very small spinules and 2-3 small, curved spines at exterolateral angle, lateral margins with a few short setae; anterior lobes unarmed, margins with long setae.

Habitat. The specimens was found in the gastropod Turritella cf. rubescens Reeve, 1849, 360-390 m depth.

Colour. Living colour unknown. In alcohol: body and appendages straw-coloured.

Distribution. Only known from the northern Gulf of California.

Remarks. Given that only two females were examined during this study, the new species is assigned to Pagurus with some reserve until an adult male specimen is available and the generic assignment is either confirmed or modified.

Pagurus findleyi n. sp. is easily distinguished from most other eastern Pacific species of Pagurus. There is, however, some similarity between Pagurus findleyi n. sp. and the three species occurring in deep water (65$980 \mathrm{~m}$ ) off Colombia, Peru and Chile: Pagurus meloi Lemaitre and Cruz Castaño, 2004; P. imarpe Haig, 1974; and P. delsolari Haig, 1974 (Lemaitre and Cruz Cataño 2004, Haig 1974). In all these species the shield is equal or slightly longer than it is broad, the ocular peduncles are short, the ocular acicles are narrow, dorsally concave, and with one subterminal or distal 
spine, the antennular peduncles are long and overreach the ocular peduncles by an entire length of the ultimate segment. The new species differs from these three species in a number of characters, including the rostrum, the armature and the setation of the chelipeds and the second and third pereopods, and in the shape and armature of the telson.

In $P$. findleyi $\mathrm{n}$. sp. the rostrum is triangular, ending in a small spine, whereas in $P$. meloi the rostrum is broadly rounded; in both species the shape and contour of the chelipeds are very similar, but they differ in the armature and setation. In $P$. meloi, the palm and fingers are unarmed and the setae are short, while $P$. findley $i \mathrm{n}$. sp. has some tubular spines and long setae. In Pagurus findleyi $\mathrm{n}$. sp. the posterior lobes of the telson are symmetrical, separated by a very shallow median cleft, and there are no spines on the lateral margins, whereas in $P$. meloi the posterior lobes are asymmetric, separated by a deep, U-shaped cleft, and the lateral margins bear a few spines.

Pagurus findleyi n. sp. is also close to P. delsolari. In both species, the rostrum is produced and ends in a distal spine, the second and third pereopods are fringed with long setae on the dorsal margin, but in $P$. delsolari the ventral margin is naked and the dactyls bear three long, close-set movable spinules near the distal margin, whereas in $P$. findleyi $\mathrm{n}$. sp. the ventral margin bears tufts of long to moderately long setae and the dactyls bear one row of long corneous spines. In addition, in $P$. findleyi $\mathrm{n}$. sp. the propodal rasp of the fourth pereopods bears three or four rows of scales and a preungual process is present at the base of the claw, while in $P$. delsolari there is a single row of scales on the rasp and no preungual process.

The telson of $P$. imarpe is also strikingly different, as it has a deep, V-shaped cleft on the posterior margin unlike the very shallow cleft in $P$. findleyi n. sp. In addition, as in $P$. delsolari, $P$. imarpe has a single row of scales on the rasp of the fourth pereopod and no preungal process (vs. four rows of scales and a preungal process in $P$. findleyi n. sp.). In $P$. imarpe the dorsal surface of palms of the chelipeds are devoid of spines and the antennal acicle is also proportionally longer than in $P$. findleyi n. sp.

Pagurus findleyi n. sp. cannot be clearly assigned to any of the 11 informal groups of Pagurus that have been proposed (see Lemaitre and Cruz-Castaño 2004). With the addition of $P$. findleyi n. sp., the eastern Pacific region now includes 54 species of Pagurus, of which 18 have been reported from the Mexican Pacific (Hendrickx 1993, Hendrickx and Harvey 1999, AyónParente and Hendrickx 2005).

\section{ACKNOWLEDGEMENTS}

MEH thanks the Instituto Tecnológico Superior de Monterrey (ITESM), Guaymas, Mexico, and particularly Guillermo Soberon, for the donation of the rest of their invertebrate collection to the Regional Collection of Marine Invertebrates (EMU), ICML, UNAM, in Mazatlán, Mexico. We also thank Joel W. Martin and Adam R. Wall for the facilities provided to MAP at the Natural History Museum of the Los Angeles County to review type material, and Adam Baldinger, Museum of Comparative Zoology, Harvard University, U.S.A., for the loan of type material. We also thank José Salgado Barragán for identifying the gastropod shells. During this study, MAP received short-term financial support from ICML, UNAM.

\section{REFERENCES}

Ayón-Parente M. 2009. Taxonomía, zoogeografía y aspectos ecológicos de los cangrejos ermitaños de la familia Diogenidae (Crustacea: Decapoda: Anomura) del Pacífico mexicano. Tesis Doctoral, Posg. Cienc. Mar y Limn. UNAM, 469 pp.

Ayón-Parente M., Hendrickx M.E. 2005. New record and colour description of the hermit crab, Pagurus nanodes Haig and Harvey (Anomura, Paguroidea, Paguridae) in the eastern tropical Pacific. Crustaceana 78(7): 885-886.

Ayón-Parente M., Hendrickx M.E. 2010. Species richness and distribution of hermit crabs of the family Diogenidae (Crustacea: Decapoda: Anomura) in the eastern Pacific. Nauplius 18(1): $1-12$.

Faxon W. 1893. Preliminary descriptions of new species of Crustacea. Reports on the dredging operations of the west coast of Central America to the Galápagos, to the west coast of Mexico, and in the Gulf of California, in charge of Alexander Agassiz, carried on the U.S. Fish Comission steamer "Albatross", during 1891, Lieut. Commander Z. L. Tanner, U. S. N. commanding. VI. Bull. Mus. Comp. Zool. 24(7): 149-220.

Faxon W. 1895. Reports on an exploration off the west coasts of Mexico, Central and South America, and off the Galápagos Islands, in charge of Alexander Agassiz, by the U. S. Fish Commision steamer "Albatross", during 1891, Lieut. Commander Z. L. Tanner, U.S.N., commanding. XV. The stalk-eyed Crustacea. Mem. Mus. Comp. Zool. 18: 1-292.

García-Gómez J. 1983. Revision of Iridopagurus (Crustacea: Decapoda: Paguridae) with the descriptions of new species from American waters. Bull. Mar. Sci. 33(1): 10-54.

Glassell S.A. 1937. The Templeton Crocker Expedition. XI. Hermit crabs from the Gulf of California and the coast of Lower California. Zoologica 22: 241-263.

Glassell S.A. 1938. Three new anomuran crabs from the Gulf of California. Allan Hancock Pac. Exped. 5: 1-6.

Gordan J. 1956. A bibliography of pagurid crabs, exclusive of Alcock, 1905. Bull. Am. Mus. Nat. Hist. 108(3): 253-352.

Haig J. 1974. Two new species of Pagurus from deep water off Peru and Chile (Decapoda, Anomura, Paguridae). Crustaceana 27(2): 119-130.

Hendrickx M.E. 1990. The stomatopod and decapod crustaceans collected during the GUAYTEC II cruise in the central Gulf of California, Mexico, with the description of a new species of Plesionika Bate (Caridea: Pandalidae). Rev. Biol. Trop. 38(1): 35-53.

Hendrickx M.E. 1993. Crustáceos decápodos del Pacífico mexicano. In: Salazar-Vallejo S.I., González N.E. (eds.), Biodiversidad Marina y Costera de México. Comisión Nacional para el Conocimiento y uso de la Biodiversidad y CIQRO, México, pp. 271-318.

Hendrickx M.E. 2005. Crustacea 6. Decapoda: Dendrobranchiata, Caridea, Palinura, Anomura and Brachyura. In: Hendrickx M.E., Brusca R.C., Findley L.T. (eds.), Listado y distribución de la Macrofauna del Golfo de California, México. Parte 1. Invertebrados. Arizona-Sonora Desert Museum. Tucson, AZ, USA, pp. 159-194.

Hendrickx M.E., Ayón-Parente M. 2011. Rediscovery of Uroptychus pubescens Faxon, 1893 (Decapoda, Anomura, Chyrostylidae) in the southern Gulf of California, Pacific coast of Mexico. Crustaceana 84(12-13): 1411-1420.

Hendrickx M.E., Harvey A.W. 1999. Checklist of anomuran crabs (Crustacea: Decapoda) from the eastern tropical Pacific. Belg. J. Zool. 129(2): 363-389. 
Lemaitre R. 1989. Revision of the genus Parapagurus (Anomura: Paguroidea; Parapaguridae), including redescriptions of the western Atlantic species. Zool. Verh. Leiden. 23: 1-6.

Lemaitre R. 1999. Crustacea Decapoda: a review of the species of the genus Parapagurus Smith, 1879 (Parapaguridae) from the Pacific and Indian Oceans. In: Crosnier, A. (ed.) Résultats des Campagnes MUSORSTOM, Volume 20. Mém. Mus. Hist. Nat., Paris. 180: 303-378.

Lemaitre R., Alvarez-León R. 1992. Crustáceos decápodos del Pacífico colombiano: Lista de especies y consideraciones zoogeográficas. An. Inst. Invest. Mar. Punta de Betín 21: 33-76.

Lemaitre R., Cruz-Castaño N. 2004. A new species of Pagurus Fabricius, 1775 from the Pacific coast of Colombia, with a checklist of eastern Pacific species of the genus. Nauplius 12(2): 71-82.

Lemaitre R., McLaughlin P.A. 2003. Revision of Pylopagurus and Tomopagurus (Crustacea: Decapoda: Paguridae), with descriptions of new genera and species. Addendum and taxonomic summary. Proc. Biol. Soc. Wash. 116(2): 464-486.

McLaughlin P.A. 1974. The hermit crabs (Crustacea: Decapoda: Paguridea) of northwestern North America. Zool. Verh. Leiden. 130: 1-396.

McLaughlin P.A. 1981. Revision of Pylopagurus and Tomopagurus (Crustacea: Decapoda: Paguridae), with description of new genera and species. Part I. Ten new genera of the Paguridae and a redescription of Tomopagurus A. Milne Edwards and Bouvier. Bull. Mar. Sci. 31(1): 1-30.

McLaughlin P.A. 1982. Revision of Pylopagurus and Tomopagurus (Crustacea: Decapoda: Paguridae), with description of new genera and species. Part 3. Agarochirus McLaughlin, Enallo- pagurus McLaughlin, and Enallopaguropsis McLaughlin. Bull. Mar. Sci. 32(4): 823-855.

McLaughlin P.A. 2003. Illustrated keys to families and genera of the superfamily Paguroidea (Crustacea: Decapoda: Anomura), with diagnosis of genera of Paguridae. Mem. Mus. Victoria 60(1): 111-144

McLaughlin P.A., Komai T., Lemaitre R., Rahayu D.L. 2010. Annotated checklist of anomuran decapod crustaceans of the world (exclusive of the Kiwaoidea and families Chirostylidae and Galatheidae of the Galatheoidea) part I - Lithodoidea, Lomisoidea and Paguroidea. Raffles Bull. Zool. suppl. 23: 5-107.

Saint Laurent M. de. 1968. Révision des genres Catapaguroides et Cestopagurus et description de quatre genres nouveaux. I. Catapagoroides A. Milne Edwards et Bouvier et Decaphyllus gen. nov. (Crustacés Décapodes Paguridae). Bull. Mus. Hist. Nat. Paris 39: 923-954.

Saint Laurent M. de. 1970. Révision des genres Catapaguroides et Cestopagurus et description de quatre genres nouveaux IV. Solenopagurus De Saint Laurent (Crustacés, Décapodes, Paguridae). Bull. Mus. Natl. Hist. Nat. $2^{\mathrm{e}}$ sér. 41(6): 1448-1458.

Scanland T., Hopkins T. 1969. A new species of hermit crab, Pylopagurus diegensis (Decapoda: Anomura), with a key for the genus in the Eastern Pacific. Pac. Sci. 23(2): 257-260.

Walton B.C. 1954. The genus Pylopagurus (Crustacea, Anomura) in the Pacific with description of two new species. Allan Hancock Pac. Exped. 18(2): 138-173.

Scient. ed.: E. Macpherson.

Received April 28, 2011. Accepted February 22, 2012.

Published online July 9, 2012. 